\title{
HARMONIZATION OF EUROPEAN COMPANY LAWS
}

\author{
ERIC STEIN*
}

\section{INTRODUCTION}

May I begin with a statement of confession and avoidance: I am not and never have been an expert in corporation law of any kind-European or American-and I shall therefore avoid any discussion of technical corporation law questions.

I am, however, interested in the corporation as an institution that plays a role in the process of integration of states. Arthur S. Miller wrote once that going national by American corporations was one of the principal reasons for the American economy's becoming national, and for the changes in the nature of the federal system that have taken place since 1787 . Once the economy became national, it meant that a continental economic system was superimposed on what was then a decentralized political order. This released powerful impulses toward centralization in the federal political system.

The analogy between the evolution in the United States and that in contemporary Western Europe is alluring, but it is, of course, dangerous as all such analogies are. Yet it is a fact that business in a politically decentralized Europe is going European, that the corporation is the principal instrumentality in this Europeanization process, and that the Common Market Treaty provides an institutional framework for a new economic system and perhaps for a new political order as well.

It is proper for us lawyers to realize that the law plays a part in this development as it did in the United States. But it is the better part of wisdom to keep in mind that in this complex process the law plays only the role-to paraphrase George Kennan-of a gentle fertilizer.

\section{The Two Processes}

In the field of corporation or company law on the Continent, two separate but closely related processes may be identified. The first is the national company law reform process, which has as its parallel the contemporary efforts in the United States to modernize state corporation laws. In Europe this involves national legislation in the individual nation-states. The second process aims at building a legal framework

* Professor of Law, University of Michigan Law School.

Full documentation relating to the materials drawn upon in this paper may be found in E. STEIN, Harmonization of European Company laws-National Reform and Transnational Coordination (1971). References to major developments which occurred after the publication of the book are given in footnotes below. The author gratefully acknowledges the assistance of Professor Alfred F. Conard of the University of Michigan Law School who read and commented on the manuscript. The author was also able to draw upon Professor Conard's address European Company Laws From an Anterican Viewpoint delivered at a colloquium on The Harmonization and Unification of Company Law in Europe at Leeds, England, September I9-2I, 1972. 
for multi-state European business, and the center of this effort is in the new institutional complex of the European Economic Community. This second process might be labeled "transnational coordination."

These two processes have interacted with varying intensity since about 1962 . But if one is interested in the cause-effect relationship, the situation gets complicated because, even before the coordination, the trend in national reforms had been in the direction of "spontaneous assimilation," that is, toward an increasing similarity among national laws, with German law serving in many respects as a model.

Modern company laws have become increasingly similar because modern industrial and post-industrial societies have become increasingly similar and face similar problems: the problem of broadening the base of stock ownership ("people's capitalism"); the problem of coping with the dissociation between corporate ownership and control ("stockholder democracy"); the problem of increasing participation of employees and other constituencies in corporate policy-making; and the problem of diversifying the law in the light of the fact that modern corporate structure must serve an increasing variety of enterprises ranging still from a small family undertaking to the conglomerate monster.

The coordination proceedings in Brussels have had some effect in strengthening the impulses toward "spontaneous assimilation." It is, however, important to keep in mind that while societal similarities have often led to similar solutions, significant differences and idiosyncrasies have emerged: the sharp disagreement over the forms of employees' participation in corporate life is a telling example-and I shall return to it.

\section{II}

The First Process: Reform of National Company Laws

All six present members of the Community either are engaged in reforming their company laws or have recently completed a partial or an overall reform. This fluidity has, on the whole, been helpful to the coordinating effort in Brussels. Germany's continual law reform has been a strong influence on the coordinating proceedings which, in turn, have influenced national reform in France and particularly in Belgium and the Netherlands.

\section{A. Germany}

In Germany, the stock company law (Aktiengesetz) has been kept remarkably up to date. The 1937 reform of that law greatly strengthened the hand of the management as against the shareholders. Drawing upon Anglo-American experience with a powerful board of directors, and skillfully capitalizing upon the Fiihrerprinzip which the National Socialist Government had sought to impose upon the entire economy, the Ministry of Justice succeeded, with Hjalmar Schacht's support, in putting through this important general reform. In a rather dialectic way, this was followed by the reform of $x 965$, which cut down management discretion somewhat-particular- 
ly as regards building hidden reserves. This latest 1965 reform was kindled by the German neo-liberals, and it was designed principally to protect shareholders and investors which, as we shall see, has been a major theme of the current reforms in other member states and of the coordination in Brussels. Today the German stock company law is the most modern, most "regulatory," and most structured of the Common Market company laws. The very same man, a high official in the Ministry of Justice in Bonn, who prepared the Government draft of the 1965 law was until recently the German spokesman in Brussels, and a very forceful spokesman indeed.

If there were such a thing as a patent for new legal institutions, Germany could claim at least four such patents in the field of company law. The first invention is a special legal form or regime for a closely held company called a "limited liability company" which has gradually spread nearly everywhere. The principal characteristics of this form are limited negotiability of shares, simple organizational structure, and relative privacy. Only the common law countries (including the United States), Scandinavia and-until I97x-the Netherlands have adhered to a single statutory regime (the stock company or corporation) for the largest and smallest of companies.

The second significant German invention is a two-tier system of corporate organization consisting of a management board (Vorstand) and a supervisory council (Aufsichtsrat). The supervisory council is a board of non-executives, elected by the shareholders, which supervises, hires, and fires the executives who run the company. This feature is gaining wide acceptance and is likely to get the official blessing of the European Economic Community.

The third German invention, elaborated greatly in the 1965 reform, blazed the trail in introducing a set of rules on "related companies" or affiliations of multiple corporations in a single enterprise (the Konzernrecht). These affiliations exist in all industrialized states, yet are ignored by most corporation codes.

The fourth-and perhaps the most famous and the most controversial inventionis the workers' "codetermination" or Mitbestimmung, which brings employees' representatives directly into the governing bodies of the stock company. In the coal, iron, and steel producing industry, the supervisory council of enterprises with over one thousand employees is composed of equal numbers of representatives of shareholders and employees. In addition, a "labor director," who is responsible for labor relations and must be approved by the workers, is a member of the management board. In all other stock companies, excepting only family-owned companies with less than five hundred employees, the employees have a one-third representation on the supervisory council. A substantial body of opinion in Germany gives this institution' credit for the long post-war period of labor peace and for the absence of pressure for increasing public control of private industry in that country. Others question its real effect and explain its relative viability by the political weakness of post-war German labor unions as compared, for instance, with the strong unions in France and in Italy. In these latter countries labor unions prefer arms-length bargaining with the manage- 
ment, increased statutory protection and a decisive influence at the plant level to participation in company administration. It is this issue of codetermination that has posed the most serious difficulty to the coordination effort at the European level.

\section{B. France}

In 1966 the French produced an impressive piece of recodification-a new comprehensive law dealing with all commercial companies and not just the stock company. It was the culmination of an effort extending over more than a quarter of a century, and it fit well into the Gaullist program of a general "renewal" of French institutions, even though it represented a relatively modest modernization.

With a sense for drama characteristic of the Gaullist regime, the law was signed on July 24 , Ig66, the ninety-ninth anniversary of the signing of its predecessor, the 1867 law. The principal value of the new codification' was that it put an end, for awhile at any rate, to what was accurately described as obscurantisme impénétrable, an impenetrable labyrinth of laws, decrees, and ordinances that had mushroomed since I867. Yet by now-only six years later-there have already been more than a dozen supplementing and amending laws and decrees, and the process toward a labyrinth has started once again:

It is interesting to note, as an instance of assimilation on the German pattern, that the 1966 French law introduced the German-type two-tier system of corporate organization-the supervisory council and management board-as an optional system available along with the single-tier board-of-directors system such as we have in American corporation laws. The move towards the German-style two-tier system was pressed by the left-wing Gaullist faction in the hope that ultimately it would lead to the adoption of the German-style workers' codetermination. But this hope did not materialize; instead the Pompidou government has implemented a variety of plans for increased stock ownership by employees. However, under the current law two members of the employees' plant committee (comité d'enterprise) may attend the sessions of the company board in an advisory capacity and the committee is entitled to receive the company's financial documents.

In its more advanced stages the French reform work has had considerable influence on the Common Market Commission work in Brussels and has been, in turn, influenced by these quarters.

A novel idea emerged in' France in I967 in the context of governmental efforts to adjust the French economy to the new dimensions of the Common Market: the groupment d'interêt économique, a greatly simplified, functional form of association available to individuals and companies wishing to join in cooperative arrangements for such purposes as joint selling or purchasing, research, exporting, or public works projects. This form has evoked so much interest in industrial circles outside France that the Common Market Commission decided to propose it for adoption by all 
members of the Community as a transition and a supplement to the proposed "European company," discussed below."

\section{Italy}

Italy already has a rather modern company law. The 1942 Civil Code integrates civil and commercial law of the country in a massive codification. Yet under the stimulus of the first center-left government coalition program of $196_{3}$, a draft reform law concerning commercial companies was worked out and went through the $\mathrm{Na}$ tional Council on Labor and Economy and a high level Interministerial Commission. Like so many reform schemes in Italy, it has been gathering dust in the Ministry since Ig66, while the Government moves from one crisis to another.

The draft would increase still further the already substantial governmental control over companies. One controversial idea under consideration was for a public authority, a court or a regulatory agency, to appoint auditors for stock companies. The reform work in Rome did not take explicit note of the Brussels operation, but in several respects it moves in the same direction.

\section{Belgium and Luxembourg}

Belgium is in the process of reforming the 1935 version of its Commercial Code of 1873 and, according to a recent report the draft was still being reviewed by the Conseil d'Etat, which is Belgium is a thorough and detailed process. The draft, like the French reform, deals with all forms of companies and is a modernization without revolutionary innovations. It reflects essentially the views and needs of the business community, and it introduces the German two-tier system as the exclusive stock company form.

The text was profoundly influenced by Belgian master comparatists such as Professors van Ryn, Heenen, and van Ommeslaghe and anticipates a number of solutions worked out by the Common Market Commission. It is quite responsive to the coordination work in the Community since these very same people have played a prominent part in that work. Indeed, the cross-fertilization or "socialization" of the small national elites of legal scholars, civil servants, and practitioners who work on law reforms at home and who get together regularly in Brussels has been perhaps the most important result of the transnational coordination process thus far.

Belgium created its Commission Bancaire to watch over corporation finance in the early thirties at almost the same time as our Securities and Exchange Commission was established for the same purpose. France followed this pattern in 1967 in setting up a Commission on Stock Exchange Transactions (Commission des opérations de bourses), which in 1970 was given expanded powers including the power of subpoena. Luxembourg has moved in the same direction.

Luxembourg has asked a Belgian expert, Professor van Ommeslaghe, to help draft

\footnotetext{
${ }^{1}$ See response to question in the European Parliament in Journal officiel des Communautés EuropEennes [E.E.C. J.O.], February 8, 1972, at $\mathrm{Cr}_{2} / 1_{3}$.
} 
a reform of its I9I5 Commercial Code and it is generally assumed that-as has been the case in the past-Luxembourg will take over the new Belgian law more or less lock, stock, and barrel.

\section{E. The Netherlands}

The last of the Six, the Netherlands, has been engaged in recodifying and consolidating its civil and commercial law. The code chapter on legal persons, including companies, is also a mild modernization. It went through the Parliament in 1960 , but has not come into effect as yet and is not expected to within the next few years.

For a number of reasons, the Netherlands found itself in a peculiarly isolated position in Brussels. First, until r97x, the Netherlands alone among the Six had only a single corporate form, since it did not use the limited liability company form. Second, in the realm of choice-of-law rules, the Netherlands alone among the Six follows the Anglo-American "state of incorporation" rule under which the law of the state of incorporation governs the company's internal affairs. The other five follow the "real seat" rule, according to which the law of the state where the company has its head office governs its internal affairs.

Third, Dutch law alone requires Ministerial approval for incorporation.

Finally, insofar as its content is concerned, Dutch company law had resembled the liberal Delaware enabling-type act more than' the laws of the other five. It was influenced strongly by British law via the large Anglo-Dutch corporations.

Because of the isolated position of the Dutch law, the Dutch delegation in Brussels was unenthusiastic (to put it mildly) about any coordination of national legislation. Yet in response to both domestic and "European" stimuli, the Dutch virtually burst with reform in I97I. Between January and July I97I, no less than eight pieces of legislation dealing with corporations went into effect." The new laws introduce a second corporate form, the "close limited liability company," thus bringing the Dutch in' line with the other five; they increase substantially the requirements for the content of corporate financial documents; and they provide for a novel shareholders' and workers' right of inquiry into the conduct of management, enforceable by court injunction. The Dutch made it clear that they adopted the injunction device from the common law system. But the most interesting aspects of this new legislative cornucopia are the enactment of the German-type two-tier system as a compulsory scheme for major companies, and a rather curious and unique co-optation procedure for the selection of members of the supervisory council. According to this new procedure, the "plant council" of the company employees and the shareholders meeting as well as the management are given the right to propose their candidates for membership in the supervisory council. The shareholders meeting and the plant council are given the right to veto any candidates who are not acceptable to them, but the veto may be overturned by the Economic and Social Council, which

\footnotetext{
${ }^{2}$ The new legislation is conveniently summarized by Professor Pieter Sanders in Le nouveau droit des sociétés et de l'enterprise aux Pays Bas, Drort ET AfraIrs, No. 207, Nov. 15, I971, at Doc. 33/71.
} 
is a government appointed body. The Netherlands is the only member state thus far to follow the German concept of workers' participation, but in a quite different form.

\section{III}

\section{The Second Process: Transnational Coordination}

As the above description' of changes in national company laws shows, national reform processes clearly tend toward assimilation of legislation in the Six. A second, intermeshing process of transnational coordination, centered in Brussels and carried forward pursuant to the European Economic Community Treaty is also occurring. What are the legal bases of this process? How does it work and how far has it progressed?

Two cardinal features of the Community Treaty-one negative and one positive -should be kept in mind. First, the Common Market Treaty does not give the Community any express power either to reform or to unify national company laws, but only "to coordinate" them and to remove obstacles to company mobility. This, at any rate, is the legal situation. It is different, for example, from the Nordic Council, where uniform law is the expressly stated objective. That is the negative side of the Treaty. The positive side is that the task of wielding this power of coordination is in the hands of Community institutions-lawmaking and judicial. These institutions provide an "organized impulse toward joint lawmaking as well as a measure of enforcement and uniform interpretation which, although still far short of a federal pattern, is unknown in any other international organization.

\section{A. The Four Coordinating Directives}

As one aspect of a "common market" the Community Treaty required the removal of all discriminatory legislative and administrative restrictions on company mobility: a company of a member state must be free to set up branches or organize subsidiaries in any other member state and these branches or subsidiaries must enjoy the full spectrum of rights and benefits enjoyed by local companies. The underlying assumption was that local nationals and companies would become increasingly involved as investors, suppliers, or creditors with companies coming in from other member states. With this assumption in mind, the Treaty made it the business of the Community to insure that national company laws be adjusted-or "coordinated"-so that all investors, shareholders, and "third parties" that do business with a company would enjoy essentially equivalent protection under the applicable company laws. Thus from the viewpoint of these parties it should not make much difference under what law the company with which they deal is organized. This objective was to be achieved by a rather unique form of Community legislation, the so-called directives. A directive is not a uniform law; in principle it is not a law in the sense of a rule which can be invoked by private parties against a company. Rather, a directive is a Community order requiring national governments and 
parliaments to modify their legislation so as to conform to specified minimum "federal-type" Community standards.

One such directive has been issued, and it has now been implemented in five of the six countries, although only Germany met the fixed deadline. The British European Communities Bill regarding accession to membership that is now going through Parliament contains a section modifying British law to make it conform with this directive. ${ }^{3}$ The directive, which did not seem to pose any difficulty for the British, lays down minimum standards of protection for investors and creditors in such matters as publication of financial statements and powers of person's and bodies representing a company (the ultra vires problem). It also reduces considerably the instances under which a company could be considered null and void. Company laws in all six member states must be modified somewhat to meet the standards of the directive.

A second directive has been proposed dealing with company capital, particularly its maintenance as affected by initial contributions and by its depletion through such means as purchase of treasury shares. ${ }^{4}$ In this case, Britain may experience some difficulty, since, for instance, the directive would require minimum capital for a stock company.

The third directive would seek to assure minimum protection of investors and third parties in fusion transactions within each member state, and it is noteworthy that, in a limited way, workers would be included in the concept of "third parties."5

The fourth proposed directive would, in effect, give some real meaning to the first directive's rules on publication of financial statements. This last directive prescribes in some detail the contents of corporate financial documents and minimum accounting standards so as to make financial information published in the member states more comparable and more meaningful. ${ }^{6}$ This text may also present some problems for the United Kingdom.

In the context of company law, the directive has become a rather controversial device. On the one hand, it has the advantage of being less rigid than uniform law in' that it often allows the states to maintain stricter requirements and other peculiarly national idiosyncrasies as long as they meet the prescribed minimum standards, and it also gives national parliaments a choice of the legal form of implementation into domestic law. In reality, however, most rules, as in the first directive for example,

\footnotetext{
${ }^{3}$ European Communities Bill (Bill 68) I972, pt. 2, §9. See also Treaty Concerning the Accesston of the Kingdom of DeNMark, Ireland, the Kingdom of Norway and tFe United Kingdom of Great Brttain and Northern Ireland to the European Economic Community and the European Atomic Energy Community and Decision of the Council of the EuRopean Communities Concerning the Accesston of the Satd States to the Europenn Conl and Steel Community, CMNd. No. 4862 (I972), E.E.C. J.O., March 27, 1972, L73 (special ed.). Annex I, at 89 provides for a technical "adaptation" of the first directive. The treaty was signed on January 22, I972, but has not been ratified as yet.

For the current draft text, see E.E.C. J.O., July I4, I970, at C89/20.

"For an English translation of the draft text, see Supp. to Bull. of THE EuR. Communimes 5-r97o.

${ }^{\circ}$ For an English translation of the draft text, see Supp. $7 / 7 x$ to BuLL. OF THE Eur. Comaunities I2-197I.
} 
are so detailed as to leave national parliaments little leeway, if any. This has been the cause of some irritation among the parliamentarians; yet the directive as a whole fails to achieve the advantages inherent in a truly uniform law.

In France and in Italy the implementation of the first directive was effected by executive action, while an act of Parliament was required in the other member states. In France, the government adopted a decree based on the regular lawmaking powers attributed to it by the 1958 Constitution, and it also issued an ordinance by virtue of a law of Parliament delegating to the government the power to implement certain types of Community directives. In Italy, the Presidential Decree was based exclusively on legislation which had delegated to the government the power to implement Community directives within a specified time period. The Committee of the Italian Parliament, which the Ministry of Justice consulted on the decree before its submission to the President, reacted with shocked disbelief when told that the sacrosanct Civil Code would be modified by simple executive action. The decree, however, was clearly within the delegating legislation. The reaction illlustrates some of the tensions between the executive and legislative branches that have arisen in the building of the Common Market.

Actually, one may notice some disenchantment with this phase of Community work: the coordination of company laws has proved much more difficult and timeconsuming than had been contemplated due to the passionate attachment of national delegations to their own laws, to the absence of any clear treaty standard as to what provisions should be made more similar, and to the cumbersome lawmaking machinery as it has evolved in the Community.

\section{B. "European Conventions"}

In addition to coordination' by directives, the Community 'Treaty seeks to advance company mobility in one other significant respect. The essential objective here is to lay down uniform conflicts-of-law rules, and the legal instrumentality is not a directive but a special type of international treaty, the so-called European Convention. These European Conventions are negotiated within the Community framework and they are linked with its institutions, particularly the Court of Justice. ${ }^{7}$ They must be approved in accordance with national constitutions like other international treaties. The United Kingdom and the other new members undertook in the Treaty of Accession to the EEC to accede to the Conventions already signed by the original members, and to enter into negotiations "in order to make the necessary adjustments thereto."

One such treaty, the Convention on Mutual Recognition of Companies and Legal

\footnotetext{
${ }^{7}$ For English translation of a recent agreement establishing a link with the Court of Justice of the Communities, see Protocols Conferring on the Court of Justice Jurisdiction to Interpret Conventions Concluded under Article 220 of the E.E.C. Treaty, Supp. 4/7I to BuLL. of THE Eur. Communimes 7-1971 at $\mathrm{x} 4$.

${ }^{8}$ Act concerning Conditions of Accession and the Adjustments to the Treaties Annexed to the Treaty of Accession, Art. 3(2) in CMND. No. 4862, supra note 3, at 9, E.E.C. J.O. L73 (special ed.) supra note 3, at I4.
} 
Persons, was adopted in 1969; but the ratification process has not been completed as yet. It concerns the divergence between the Netherlands and the other Five as regards the basic choice-of-law rule for corporation law. The Netherlands rule looks to the law of the state of the company's incorporation to determine whether the company is a legal person, whether it is validly organized, and what law governs its internal affairs; the other five member states follow essentially the continental "real seat" rule that considers the law of the state of the company's head office its governing law. Clearly, a company would not be very free to "move" if, when it crossed the border, it would not be recognized as a legal person, or if it were required to take on a new management structure, or if its shareholders lost their preemptive rights, or if its free surplus became statutory reserve-in' other words, if it became entirely subject to the law of its new location. The new Convention reduces this danger by reducing the scope of the "real seat" conflict rule, a rule that is not viable in a regional market setting. In fact, the Convention goes a step or two beyond the 1956 Hague Convention toward a stricter obligation to recognize foreign companies.

Another European Convention still in the drafting stage would facilitate corporate fusion across national frontiers within the Common Market. It would build on the directive regulating domestic fusion discussed earlier. ${ }^{9}$ In the present state of continental company laws, fusion in the technical sense appears to be quite impractical. The new Convention would bring about the necessary modifications in national company laws to make such fusion' across frontiers viable. Taken in conjunction with a pending directive which will regulate the tax problems arising in connection with transnational fusion, the new Convention ought to be a significant piece of Community law.

The work on the fusion Convention, however, is deadlocked on two issues: first, the German apprehension that German companies and entrepreneurs could use fusion with foreign companies for the purpose of avoiding the German law on workers' codetermination, and second, French insistence that companies organized within the Community but controlled from outside the Community should be denied the benefits of the new treaty. Clearly, the latter issue is of direct interest to the many American corporations which control subsidiary companies organized under the laws of the member states.

A similar deadlock is encountered in another project which originally was also to have been realized in the form of a European' Convention. This is the proposal for the so-called European company, a new form of corporate organization which would be available to enterprises doing business on a European scale. This new company law would be added to, and coexist with, the present national company laws. The Common Market Commission has proposed a truly "European" company, like the Dominion Company in Canada-that is, it would be a company organized not under national law but under Community law that would regulate

\footnotetext{
- See text accompanying note 5 supra.
} 
in detail its internal organization, an'd it would be registered at the Court of Justice of the Communities. More recently, the Commission has made the radical suggestion that, since the Common Market Treaty fails to provide specific authorization for this sort of institution, the new law should be adopted not by a Convention but as a "regulation" under the "necessary and proper laws" clause of the Common Market Treaty, the famous Article 235, that allows Community institutions to fill gaps in the Treaty under specified circumstances. A Community regulation is the most advanced form of Community legislation: like a federal statute, it has immediate and direct effect as domestic law in the member states.

\section{CONCLUSION}

Work in the entire company law field began to slow down about 1970, principally in anticipation of the accession of the United Kingdom, Denmark, Ireland, and Norway, but also because of the extraordinarily over-crowded legislative docket of the Council of Ministers, the central lawmaking institution in the Community. The Council has had a multitude of bills or proposals before it, and it has been concerned with matters that required more urgent attention than did the coordination of company law.

Clearly, the accession of the new members with company law systems based on common law and Scandinavian law will not make things any easier, although one should not exaggerate the difficulty. In 1969 the Scandinavian countries (including Finland and Sweden which, unlike Denmark and Norway, are not acceding to the Community) worked out a tentative draft of their own uniform stock company law. Thus, Scandinavian views also will have to be taken into account in the coordination process. It has been suggested earlier that the first coordination directive, which is already on' the books will not pose any implementation problems in the United Kingdom. But I would venture to say that the present texts of the other measures discussed above, which are still on the drafting board, may have to be modified before they become the law in the enlarged Community. I was interested in the report that Mr. Crosland, president of the British Board of Trade, was quoted as favoring the European "federal-type" company.

We all are aware that lawmaking at the national level in a pluralistic society is an immensely laborious process. This is confirmed by the experience with national company law reforms on the Continent, particularly since company law is one of the core private law disciplines, historically encrusted with special interests. It is thus not surprising that the process of coordinating national laws at a transnational level has proved even more laborious and difficult. 